\title{
Comparative Studies of Yeast and Sugarcane Invertase
}

\author{
Alex G. Alexander ${ }^{1}$
}

INTRODUCTION

Sucrose inversion is essential for the normal growth and development of sugarcane. However, from the viewpoint of the sugar producer, inversion is undesirable whenever it prevents a planting or variety from achieving maximum sucrose storage, or when sucrose of ripened cane is inverted before the crop can be milled. Only under conditions of controlled water supply can the phenomenon be regulated by cultural means. Such requirements are seldom met in the sugar-producing world, and at best give only an indirect approach to the actual mechanisms involved in sucrose inversion.

There is a need for greater knowledge of sugarcane invertase. Thorough understanding of the enzyme's behavior and work potential might permit its suppression to a point just above the minimum biochemical requirement. This would enable producers to control inversion directly, regardless of the climatic factors and cultural requirements imposed upon a given area.

Sugarcane invertase has been studied from the standpoint of number and properties $(3,6,20),{ }^{2}$ physiological roles $(4,17,19)$, and behavior in plants subjected to various treatments $(5,7,14,81)$. Yet the cumulative knowledge is small. A further shortcoming has been an almost exclusive use of sucrose as the substrate most suitable for invertase assay. The act of sucrose inversion does not in itself tell us much about the enzyme. One cannot assume, for example, that the vast research effort given yeast invertase over more than a century is applicable to the sugarcane catalyst. ${ }^{3}$ Conversely, the simple demonstration that cane and yeast invertases are identical would release a bonanza of knowledge in support of sugarcane scientists.

Recent findings suggest that cane invertase employs an extremely complex action pattern to hydrolyze a number of sugar substrates (8). A major objective of the present studies was to identify specific enzyme types responsible for the action spectrum. A second objective was to compare the

1 Plant Physiologist, Agricultural Experiment Station, Mayagüez Campus, University of Puerto Rico, Río Piedras, P.R.

2 Italic numbers in parentheses refer to Literature Cited, pp. 55-6.

${ }^{3}$ Studies of yeast invertase can be dated from the year 1828 , when sucrose fermentation was shown to require water (28). Reviews by Neuberg and Mandl (28) and by Myrback (27) summarize much of the work relating to this enzyme. 
action patterns of cane and yeast invertases in order to determine whether the two systems are identical.

\section{EXPERIMENTAL PROCEDURE}

Sugarcane invertase was prepared from lyophilized immature storage tissues of 16-iveek-old plants of the variety P. R. 980. All plants were grown in sand culture with a balanced nutrient supply, ${ }^{4}$ and finely ground tissues were extracted with water at $22^{\circ} \mathrm{C}$. Extracts were clarified by passage through cheesecloth and by subsequent centrifuging for 10 minutes at 3,000 r.p.m. Invertase was precipitated from the supernatant liquid with solid ammonium sulfate at $\mathrm{pH}$ 5.6. The latter step yields about 95 percent of the enzyme between 38- and 52-percent saturation. The invertasecontaining precipitate was taken up in water and clarified with the centrifuge. It was then dialyzed against distilled water for 2 hours and reclarified by centrifuging at 3,500 r.p.m. for 20 minutes.

The next step involved filtration of the invertase preparation through a $2.5 \times 40-\mathrm{cm}$. column of G-200 Sephadex. ${ }^{5}$ This procedure successfully isolates cane invertase from contaminant amylase, phosphatase, and noncatalytic protein. Composed of highly cross-linked dextrans which act as a molecular sieve, Sephadex was soaked in water for about 10 minutes and slowly packed by gravity in an air-free column. Ten to fifteen milliliters of invertase preparation were absorbed on the gel and eluted with distilled water. Samples of all effluent fractions were assayed for invertase by a colorimetric, reducing-sugar method previously described ( 8 ). Peak-activity fractions were combined and refrigerated at $4^{\circ} \mathrm{C}$.

Yeast invertase was obtained from Difco Laboratories, Detroit, Mich. The preparation was supplied as a desiccated extract of yeast cells, to which water was added just prior to use. Both yeast and cane invertase gave identical values for $\mathrm{Km}$ and $\mathrm{pH}$ optima with sucrose. Their paper electrophoresis and gel filtration behavior was virtually indistinguishable when sucrose was used as substrate. ${ }^{6}$ The aqueous dilution suggested by Difco Laboratories contained only about one-fifth as much protein as the cane preparation.

For both sugarcane and yeast invertase the standard reaction digest was

${ }_{4}$ Nutrient concentrations, expressed as milliequivalents per liter, were provided as follows: Nitrate, 10; phosphate, 6; potassium, 5 ; calcium, 3 ; magnesium, 2 ; and sulfate, 2. Micronutrients, expressed as parts per million, were supplied as follows: Boron, 0.05; copper, 0.02; manganese, 0.50 ; molybdenum, 0.01 ; and iron, 1.0 .

${ }^{5}$ Farmacia of Fine Chemicals, Rochester, Minn.

${ }^{6}$ An excellent study of yeast-invertase purification and properties was recently published by Neuman and Lampen (29). Principal results were reported from a mutant obtained by ultraviolet irradiation of strain saccharomyces 303-67. The enzyme was produced with a 0.3 -percent yeast extract from Difco Laboratories. 
composed as follows: $1.0 \mathrm{ml}$. of acetate buffer ( $\mathrm{pH} 5.5) ; 1.0 \mathrm{ml}$. of 5-percent substrate solution; $0.5 \mathrm{ml}$. of silicon ( $\mathrm{Si}$ ) solution or water, and 0.5 $\mathrm{ml}$. of enzyme. All reactions were run at approximately $37^{\circ} \mathrm{C}$. Experiments of more than 12 hours duration were conducted under toluene. Samples of cane- and yeast-invertase digests were withdrawn immediately after mixing of the enzyme and substrate, and were inactivated by a 10-minute submersion in boiling water. Other samples were withdrawn and inactivated at intervals ranging from 30 minutes to 72 hours. The Si source was sodium metasilicate, $\mathrm{Na}_{2} \mathrm{SiO}_{3} \cdot 9 \mathrm{H}_{2} \mathrm{O}$.

Samples of inactivated digests were chromatographed on Whatman No. 1 filter paper, using the solvent mixture butanol-pyridine-water $(6: 4: 3, \mathrm{v} / \mathrm{v})$ in one dimension. Spots representing substrates and products were developed by the silver nitrate "dip" method of Dube and Nordin (14). Dried chromatograms were first submerged in acetone saturated with silver nitrate. After drying they were immersed in a 0.4-percent solution of $\mathrm{NaOH}$ in methanol and allowed to remain until spots were clearly defined. Chromatograms were dried after washing and stabilization in aqueous 10 percent sodium thiosulfate.

\section{RESULTS AND DISCUSSION}

\section{VARIABLE ACTION BY YEAST AND SUGARCANE PREPARATIONS}

Earlier studies with cane invertase suggested that linkages other than the fructosidic linkage of sucrose can be hydrolyzed (6). This was verified by the present experiments. However, broad discrepancies were found in the relative action capabilities of cane and yeast invertases.

The chromatogram shown in figure 1 summarizes much of our invertase knowledge at the beginning of this study. This includes the appearance of four products from raffinose, and an abrupt inhibition by Si of both sucrose and raffinose hydrolysis. Raffinose is a nonreducing trisaccharide ${ }^{7}$ whose structure includes the configurations for melibiose and sucrose (18):

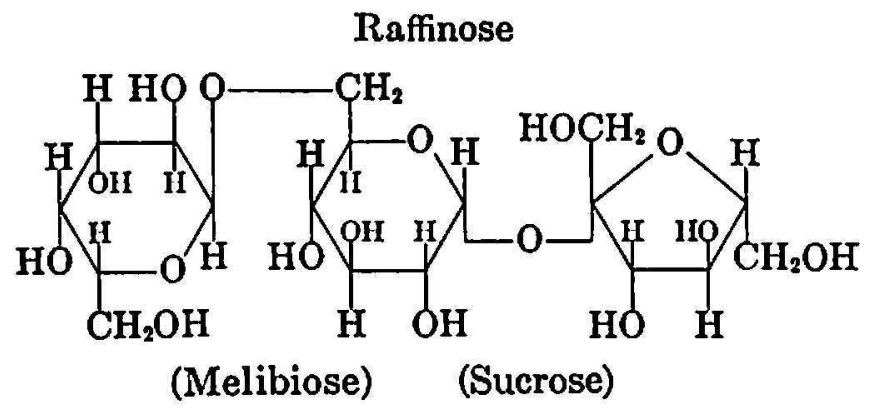

It was suggested earlier that the $1 \rightarrow 6$ galactose-glucose linkage must be

7 Raffinose is technically a $0-\alpha-D$-galactopyranosyl-(1 $\rightarrow 6)-0-\alpha-\mathrm{D}$-glucopyranosyl$(1 \rightarrow 2)-\beta$-D-fruct of uranoside. 
broken, in addition to the $1 \rightarrow 2$ glucose-fructose linkage, in order to account for all four products (6). One would anticipate only two products, fructose and melibiose, if the fructosidic linkage alone were attacked. Two products did, in fact, appear with yeast invertase (fig. 2), confirming that the latter is a $\beta$-fructofuranosidase.

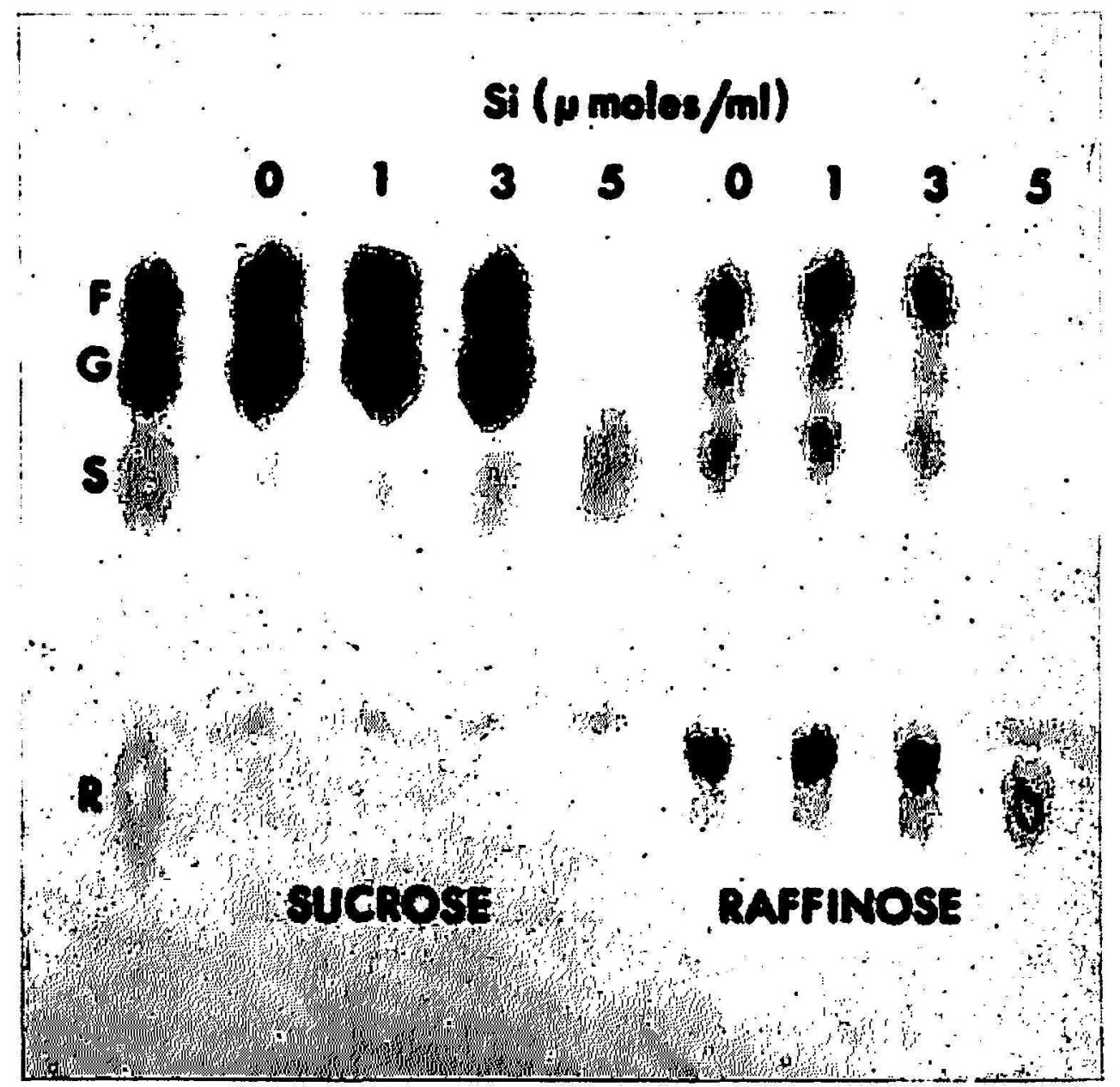

FIG. 1.-Silicon inhibition of sugarcane invertase acting upon sucrose and raffinose. Details of enzyme and chromatography methodology are described under Experimental Procedure (pp. 42-3).

In other experiments the disacharide melibiose was employed directly as substrate (fig. 3):

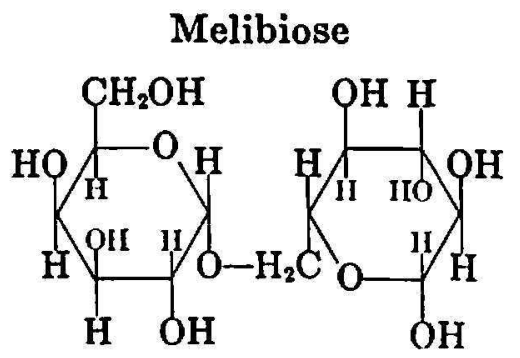

Appearance of the products glucose and galactose is supporting evidence 
for breakage of the $1 \rightarrow 6$ linkage by the sugarcane preparation. Yeast invertase was tested concurrently and yielded no products. This again suggests that the yeast enzyme cannot act in the absence of a terminal fructosidic linkage.

The actual performance of melibiose hydrolysis must be credited to an $\alpha$-galactosidase, technically a true melibiase. This enzyme is present.

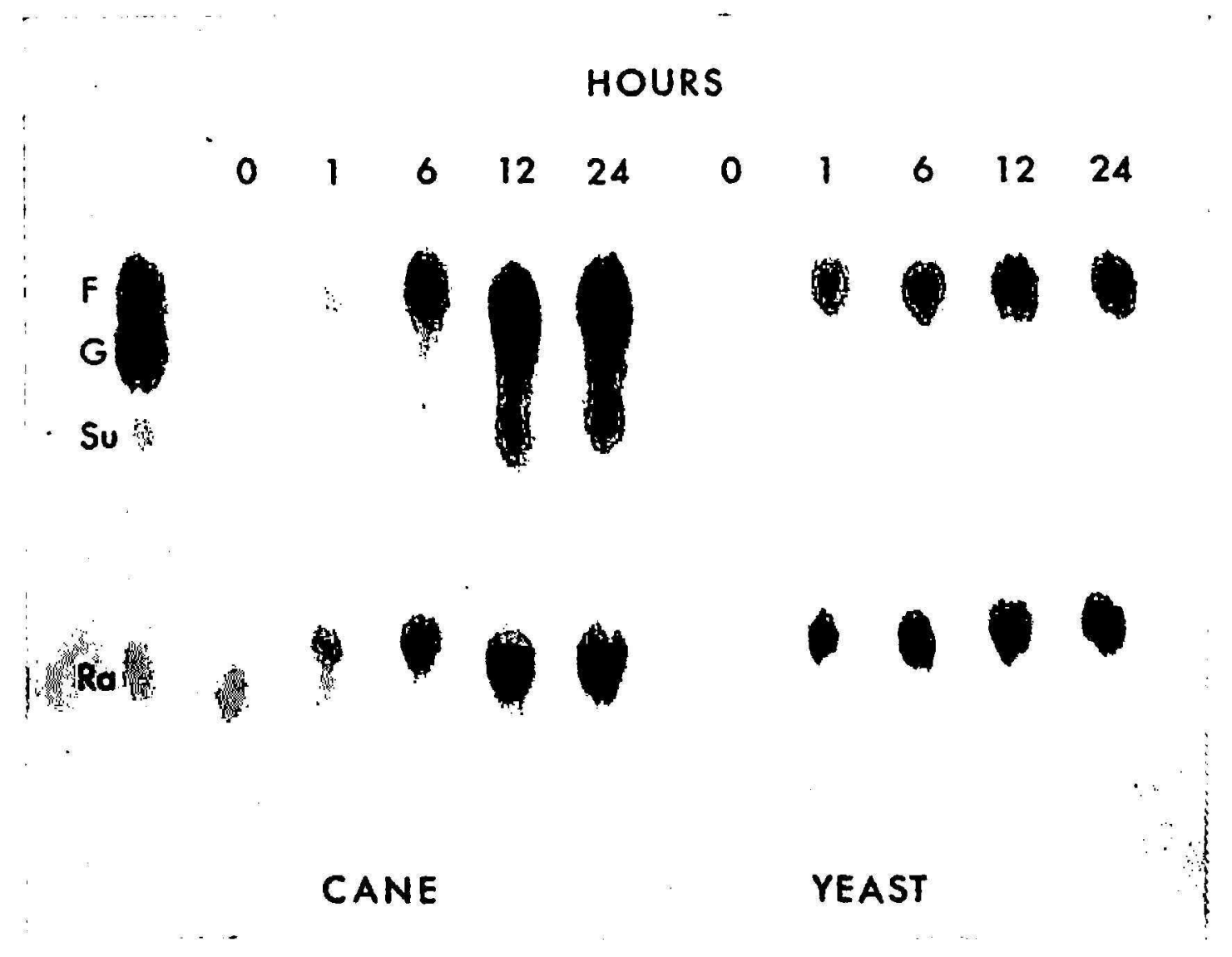

FIG. 2.-Comparative action of sugarcane and yeast invertase against the trisaccharide raffinose. Fructose and melibiose are the 2 yeast-invertase products. Cane invertase yielded fructose, melibiose, galactose and glucose. See Experimental Procedure (pp. 42-3) for technical details.

in brewers' yeasts (2) but not bakers' or ale yeasts $(12,16)$. It is interesting that such an enzyme is a constituent of the cane invertase complex. Botanically speaking it must have been carried among countless generations, yet no major biochemical function can be discerned.

The precise breakage point of the $1 \rightarrow 6$ linkage is not clear. Nor is it known whether the reaction takes place against intact raffinose or only against the melibiose produced by fructosidase action. In any event the fructosidase reaction seems sufficiently strong so as not to be rate-limiting.

Cane and yeast invertase action was also compared against the substrate stachyose (fig. 4). Stachyose is a tetrasaccharide composed of a trisaccha- 


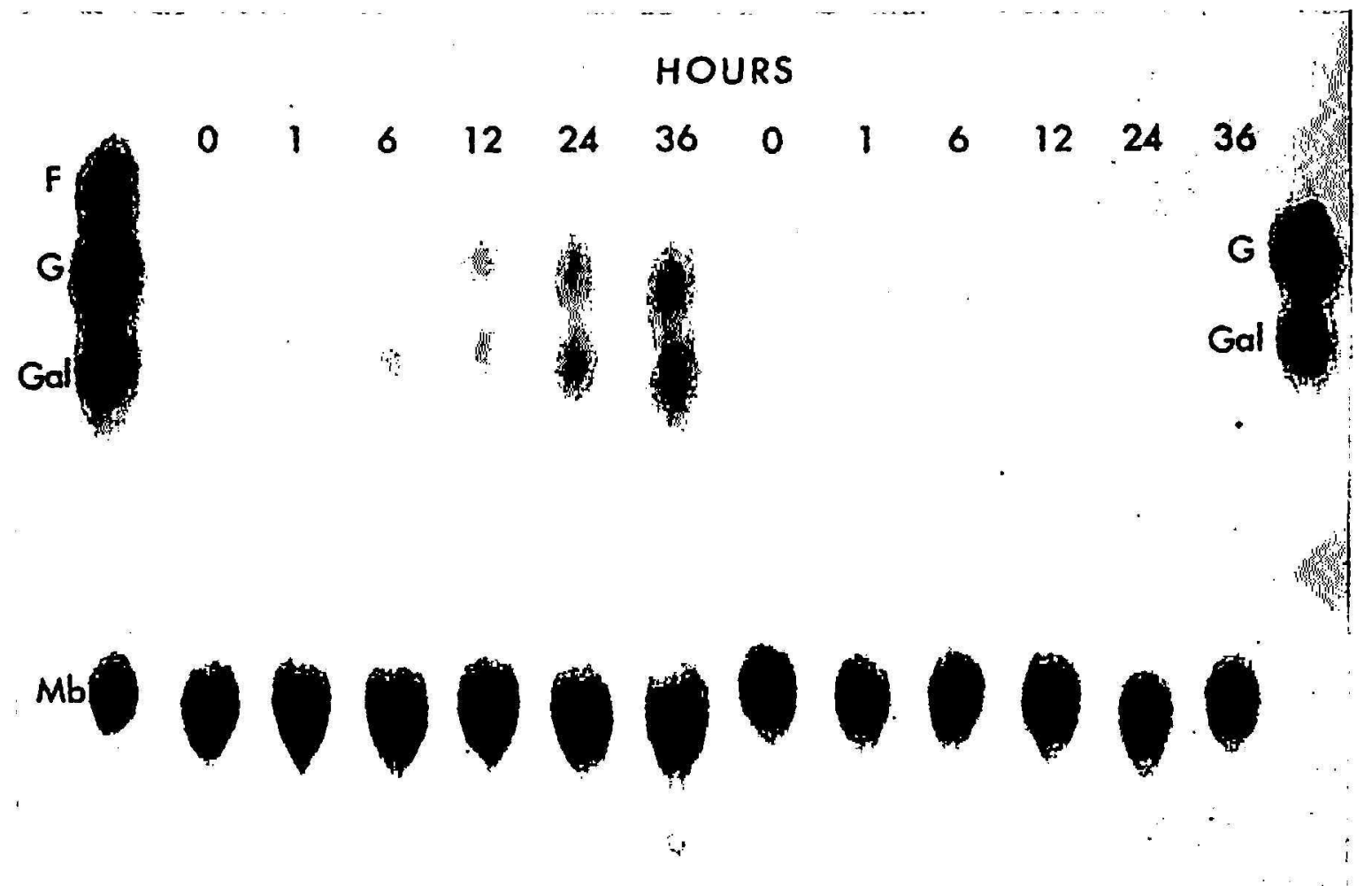

St

CANE

YEAST

Frg. 3.-Action of sugarcane and yeast invertase against the disaccharide melibiose. Glucose and galactose are produced by cane invertase; whereas no products are obtained with yeast invertase. See Experimental Procedure for technical details.

ride, manninotriose, and a terminal $d$-fructose (pp. 42-3):

\section{Stachyose}

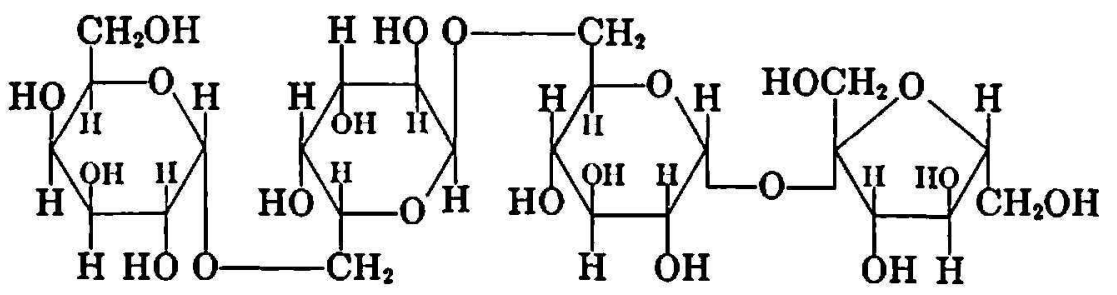

Terminal galactose and fructose residues are present as they are in raffinose. Thus the action of yeast invertase should have yielded two products, fructose and manninotriose. Examination of figure 4 shows that this occurred. A trace of contaminant sugar similar to melibiose in mobility was present in all digests regardless of reaction time. ${ }^{8}$

8 No attempt was made to further purify the substrates prior to use. Lach substrate was usually found to be chromatographically pure. 
On the other hand, cane invertase was confronted with an opportunity for secondary galactosidase action in addition to the $\alpha$-galactosidase and $\beta$-fructosidase activity already demonstrated. With raffinose, glucose appears as a consequence of fructosidase plus galactosidase action. With stachyose, however, specific hydrolysis of the interior $\alpha$-d-galactopy-

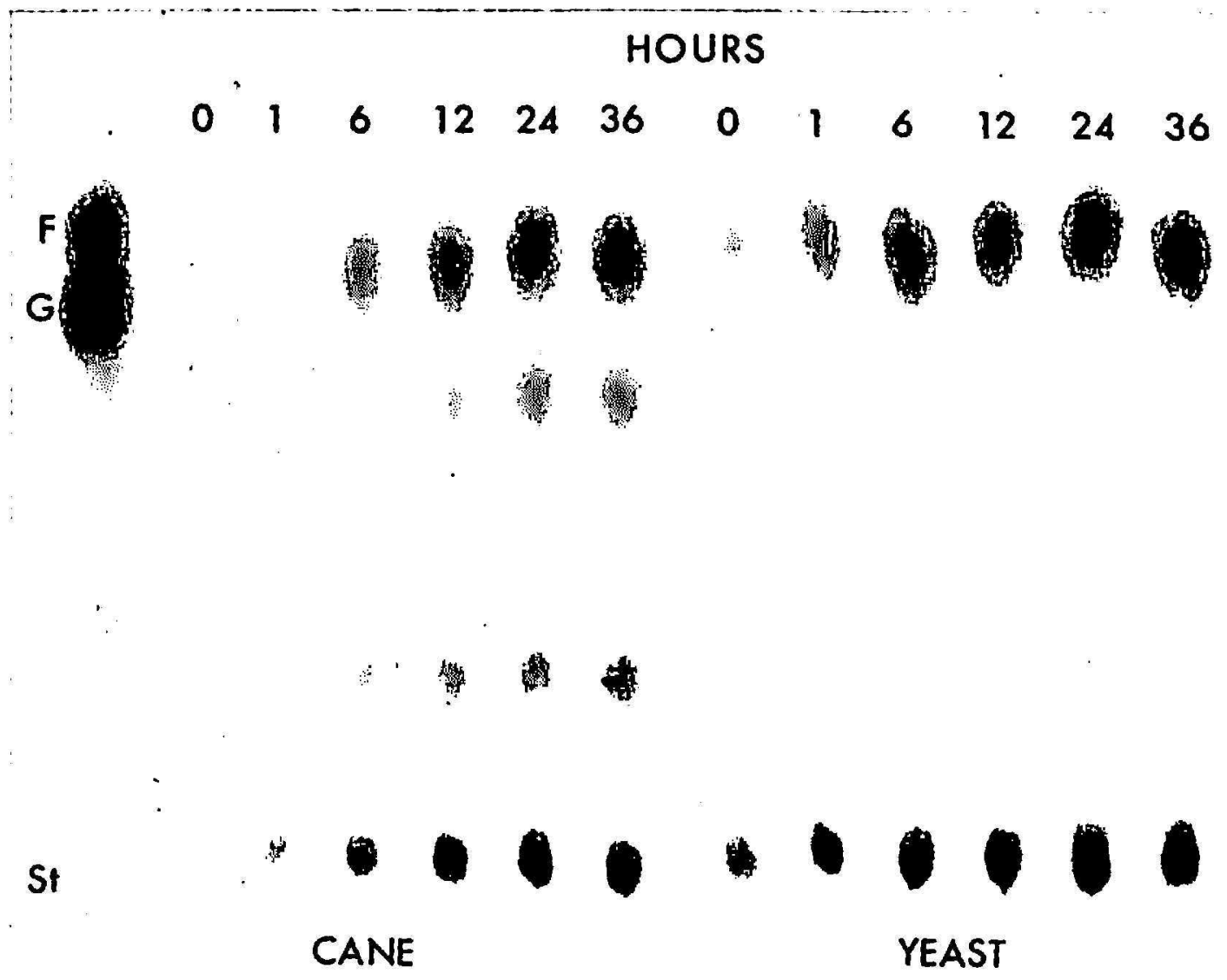

FIG. 4.-Comparative action of sugarcane and yeast invertase against the tetrasaccharide, stachyose. Fructose is the lone identified product of yeast invertase, while fructose, galactose, and melibiose are produced by cane-invertase action.

ranosyl-(1 $\rightarrow 6)$ - $\alpha$-D-glucopyranosyl linkage must occur for free glucose to appear as a product. Again a review of figure 4 shows that four products were yielded by the cane-invertase preparation. These include fructose, galactose, manninotriose, and an unidentified sugar similar to melibiose in mobility. No $d$-glucose was produced. Thus it is concluded that the interior $1 \rightarrow 6$ linkage between galactose and glucose was impervious to action by the cane preparation. The unidentified product must therefore have been the dissacharide $\alpha$ - $d$-galactopyranosyl-( $(\rightarrow 6)$ - $d$-glucose: 


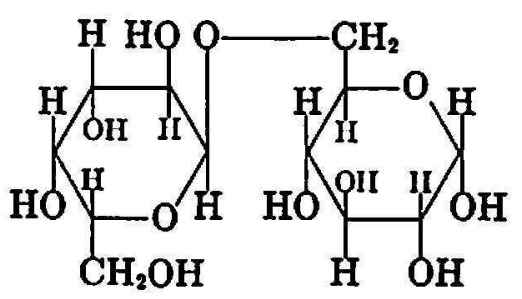

Why this dissacharide was not attacked, while melibiose was, is not easily explained on the basis of available structural formulas. The cane

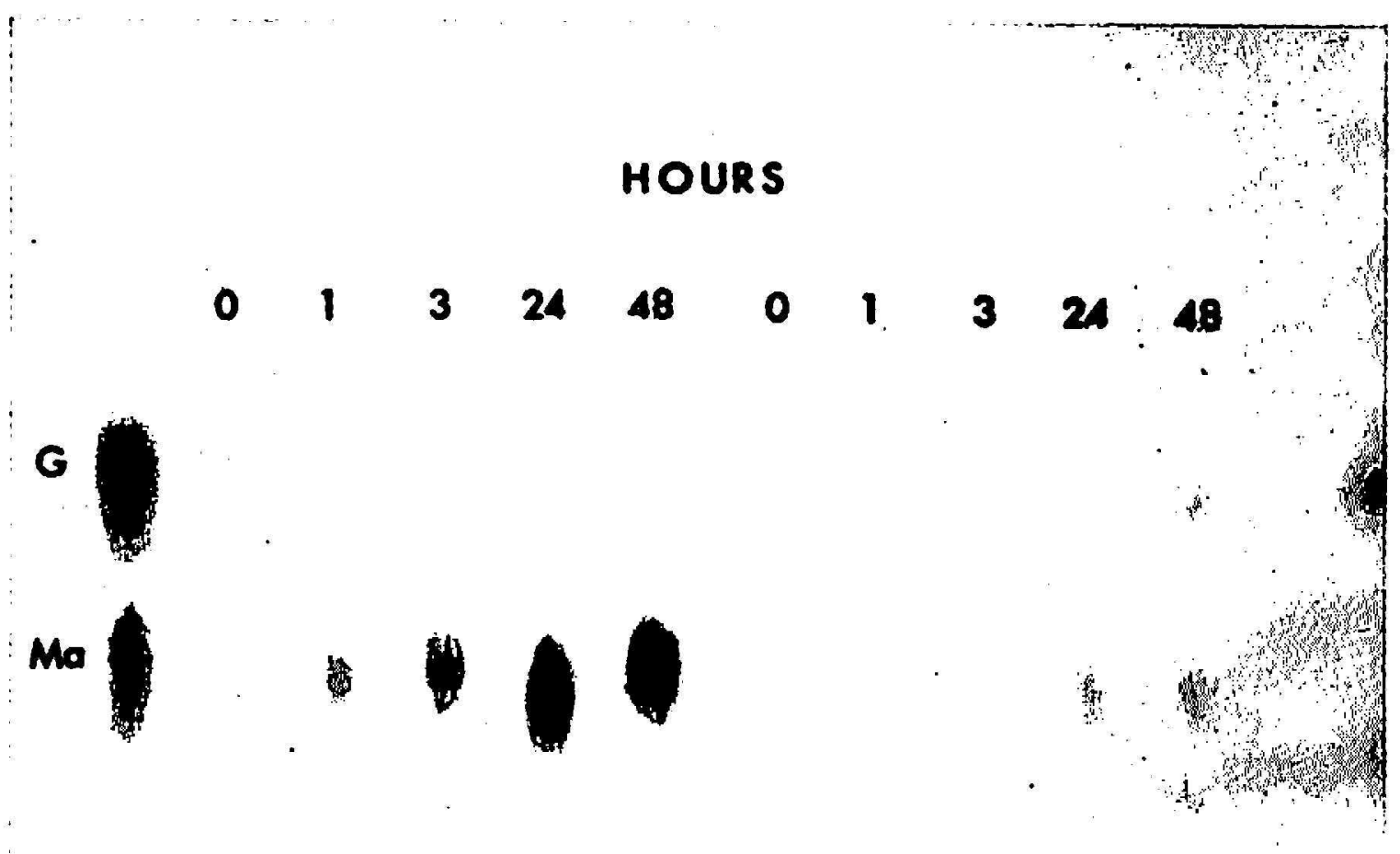

CANE

YEAST

Fig. 5.-Action of sugarcane and yeast invertase against soluble potato starch. The disaccharide maltose, produced by cane invertase, is the only major product.

enzyme apparently distinguished a structural difference of considerable magnitude. Structural reports by Onuki $(30,31)$ and by Laidlaw and Wylam (2S) have not been in complete agreement with respect to the $d$-galactosyl $\rightarrow d$-glucose linkage.

It was now reasonably certain that the yeast invertase was capable only of $\beta$-fructosidase activity, yet a major question remained as to whether cane invertase would attack $\alpha$ - $(1 \rightarrow 6)$-glucosidic linkages. Both enzyme preparations were therefore employed in prolonged digestions of soluble potato starch. As illustrated by figure 5, maltose was the lone product of 
cane invertase, while yeast invertase was totally inactive. It was therefore concluded that the sugarcane invertase complex has the ability to hydrolyze $\beta$-fructosidic, $\alpha$-galactosidic, and $\alpha$-glucosidic linkages.

It remained to test the fructosidase potential of both preparations against a polysaccharide composed solely of fructose residues. For this purpose

\section{HOURS}

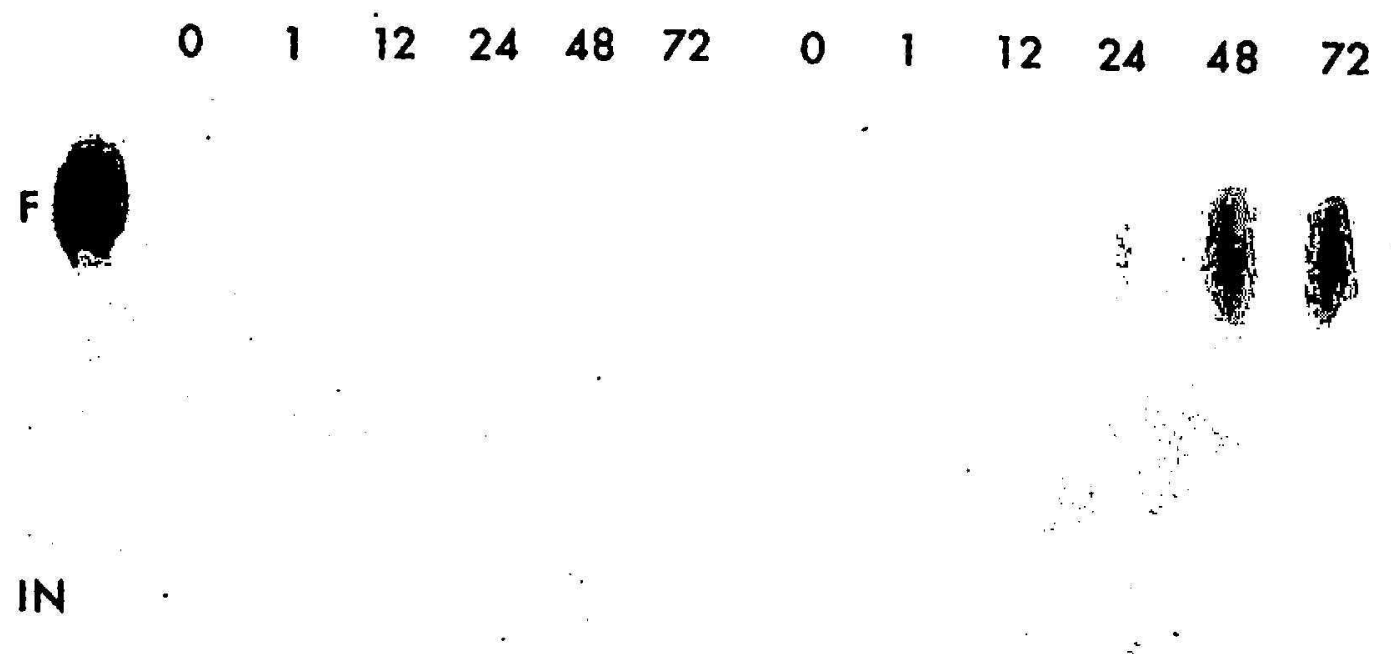

CANE

YEAST

Fic. 6.-Sugarcane and yeast-invertase action against the fructoside inulin. Fructose is liberated only by prolonged yeast-invertase action, and may indicate the presence of a contaminant inulase.

inulin was employed as substrate in a series of prolonged digestion experiments (fig. 6).

Inulin is a polysaccharide comprised of a linear sequence of about 33 fructofuranose units joined together by $\beta, 2 \rightarrow 1$-glycosidic linkages (15). $d$-fructose is liberated upon hydrolysis, and, as is true of sucrose, raffinose and stachyose, inulin is reportedly hydrolyzed by yeast invertase (18). During the present studies inulin was not acted upon by cane invertase and only reluctantly so by the yeast enzyme (fig. 6). It is not certain whether the product illustrated in figure 6 is in fact d-fructose. A small number of 
$d$-glucose units may be present in inulin $(21,32)$, and this might have complicated the normal union of fructosidase with substrate. The inulin reaction might also require a different $\mathrm{pH}$ optimum than does sucrose inversion. However, it is more probable that inulin hydrolysis requires another enzyme, an inulase, as suggested by Baumann and Pigman (13). In this way the weak yeast invertase action against inulin is explained as the work of a contaminant inulase, while the fructosidase constituents of both cane and yeast invertase were inactive in the presence of a relatively long-chain fructoside. Failure of cane invertase to act upon inulin, while readily hydrolyzing starch, offers food for thought as to its origin and purpose in sugarcane.

\section{INACTIVATION OF CANE AND YEAST INVERTASE BY SILICON}

Earlier work with sugarcane invertase revealed a complete inhibition of activity by $\mathrm{Si}(6,8)$. Some evidence suggested that the enzyme is altered so that it may perform work other than sucrose hydrolysis ( 8 ). Silicon was therefore included during the present studies to evaluate its effects on distinct types of invertase.

Figure 7 illustrates a total inhibition of yeast and cane preparations by $\mathrm{Si}$. The effective concentration lay between 2 and $3 \mu$ moles per milliliter of digest. Further Si tests with raffinose (fig. S), stachyose, and melibiose showed a precise and consistent inhibition between 2 and $3 \mu$ moles of Si. Thus the enzymes are indistinguishable on the basis of Si inactivation.

Physiological roles of $\mathrm{Si}$ in sugarcane, and indeed in higher plants, remain almost totally obscure. It is the second most abundant element on earth and more $\mathrm{Si}$ is absorbed by sugarcane than any other mineral element $(9,11)$. An obvious structural role is indicated by the siliceous skeletons which remain upon destruction of the organic matter. It was recently proposed that a biochemical role of $\mathrm{Si}$ in sugarcane might be the suppression of invertase, amylase, acid phosphatase, and ATP-ase (8).

A key to the mechanism of $\mathrm{Si}$ action against invertase may lie in the unusually narrow concentration range at which the element becomes inhibitory. Experiments have shown that inactivation occurs between 2.7 and $2.9 \mu$ moles of Si per milliliter for both yeast and cane preparations (fig. 9). While diverse invertase types might all be inhibited by some level of $\mathrm{Si}$, it seems unlikely that the distinct cane and yeast systems would have identical inhibitory concentrations. Rather, a change in $\mathrm{Si}$ (silicic acid) itself might occur with increasing concentration, and this in sufficient magnitude to block hydrolysis regardless of varying enzyme properties. Such a change might be caused by increased acidity with subsequently higher polymerization (34) as the $\mathrm{Si}$ level is raised. Yet this is not very plausible in a buffered enzyme digest. Another possibility is the synthesis 
STUDIES OF YEAST AND SUGARCANE INVERTASE

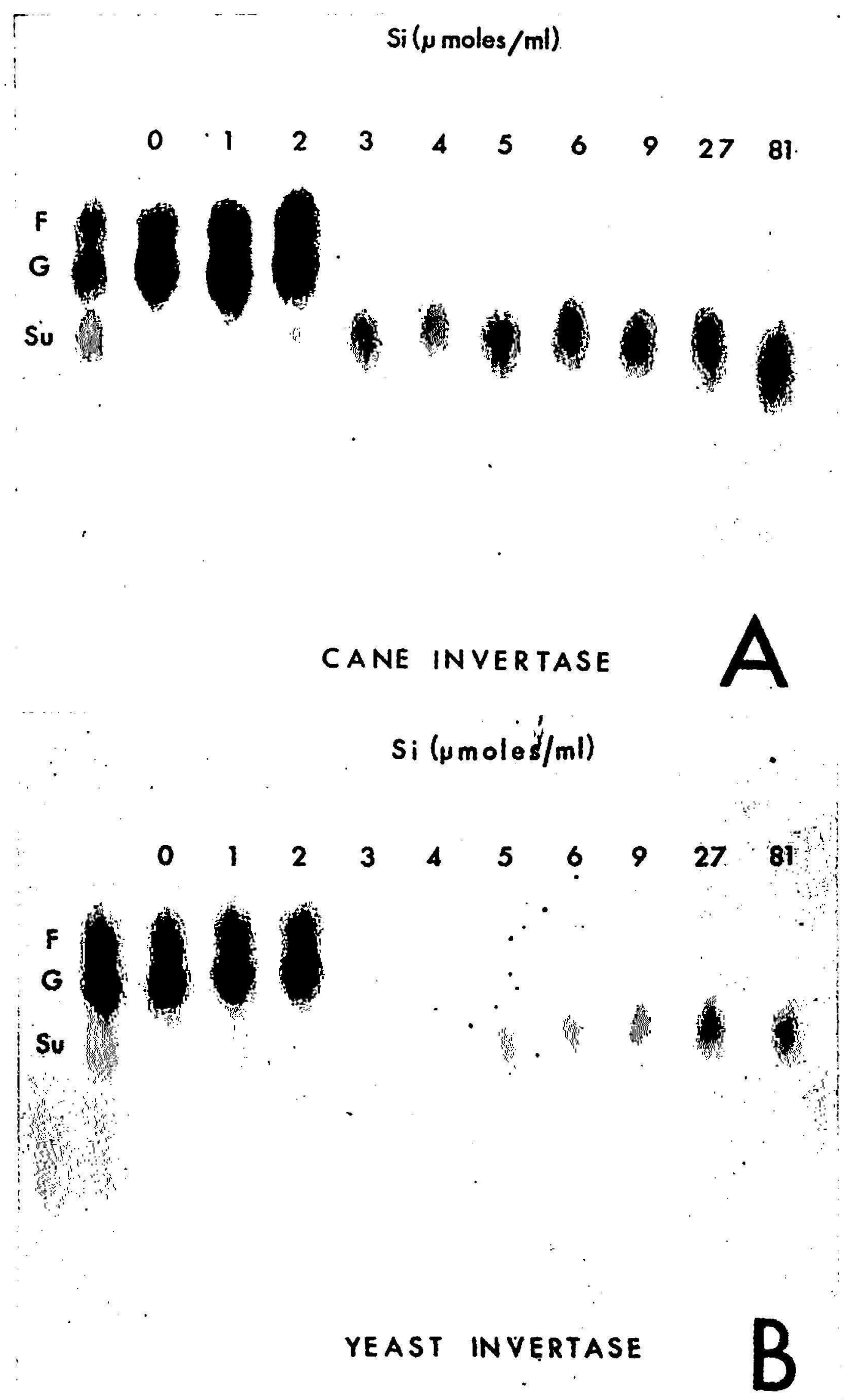

FIG. 7.-Invertase inhibition by $\mathrm{Si}$ : A, cane invertase; $\mathrm{B}$, yeast invertase. 
of a crystal structure involving silicic acid within the enzyme digest. The equation describing its formation should then incorporate factors such as $\mathrm{pH}$ and temperature (26), salt concentration, intermicellar liquid and its interaction with the gel surface (25), effects of protein-silicate complexes (10), ion-exchange properties of the crystalline silica (22), porosity of the structure (1), selectivity of crystal-protein relationships (24), and effective

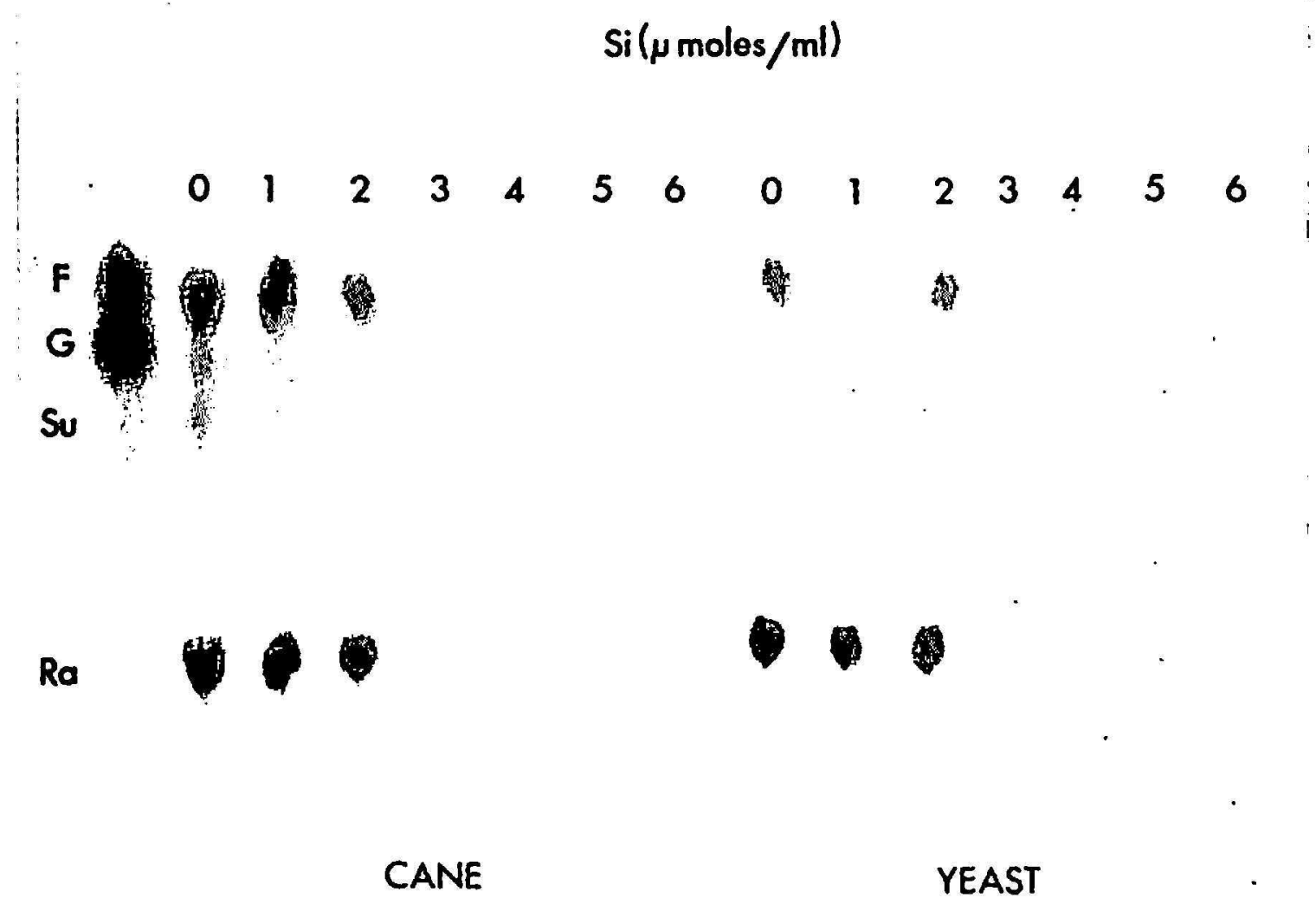

FIG. 8.-Silicon inhibition of cane and yeast invertase acting upon the substrate raffinose.

water concentration of the digest. The apparent affinity of $\mathrm{Si}$ for cane hydrolytic enzymes (invertase, amylase, phosphatase, ATP-ase) suggests a possible relationship between a silicic acid gel and the water involved in actual hydrolysis.

BOTANICAL SIGNIFICANCE OF CANE INVERTASE: A THEORY OF ORIGIN

To some degree the differences observed between cane and yeast invertase are attributable to differences of purity and of preparation. The 
procedure for cane invertase is not especially elaborate and the entire process, including dialysis, is completed in less than a day. While removal of contaminant amylase, phosphatase, and oxidase systems was virtually complete, specific activity of the cane preparation was seldom more than about 20 percent of yeast-invertase values. On the other hand, no autolysis steps were employed to increase cane invertase yield. Commercial invertase

\section{$\mathrm{Si}(\mu \mathrm{moles} / \mathrm{ml})$}

FIc. 9.-Paper chromatogram illustrating the inhibition of cane and yeast invertase by $\mathrm{Si}$ between 2.4 and $2.9 \mu$ moles per milliliter of digest.

is prepared by allowing yeast to autolyze in the presence of toluene or another suitable antiseptic. Fermentation is avoided by maintaining high sugar concentrations in the neighborhood of 50 percent. According to the method of Adams and Hudson (26), autolysis proceeds for several days, the clarified liquid is dialyzed for several more days, and the preparation is then allowed to age for 1 or 2 weeks before inert material is removed by acidification with acetic acid.

Yet regardless of differences in preparation, the cane invertase appears to be a far more highly developed system. It could perform effectively in 
biochemical sequences involving numerous sugar substrates. The yeast enzyme would be equally effective only with substrates having a terminal $d$-fructose residue. One might assume that an enzyme comparable to yeast fructosidase had developed in one-celled plants literally hundreds of millions of years before sugarcane appeared on earth. Conversely, the physiological and biochemical transformations of carbohydrate in a higher plant such as sugarcane require more complex catalysts than those of primitive plant forms.

In certain respects the sugarcane invertase employed herein is more nearly identical with cane amylase than with yeast invertase. Their properties of solubility, $\mathrm{pH}$ and temperature optima, activation, and inhibition are virtually identical. Their differences lie in variable distribution patterns among cane tissues and inability of amylase to hydrolyze sucrose. It is possible that cane invertase and amylase are derived from a common enzyme ancestor. The latter probably evolved from a progression of more primitive carbohydrases which may or may not have been related to yeast types. An increasingly complex sugar chemistry, involving glucosides and galactosides, would account for their need. In any event no direct relationship between cane invertase and yeast invertase is visualized.

\section{SUMMARY}

Comparative studies of sugarcane invertase and a commercial yeast invertase were conducted. There were two objectives: 1 , To identify specific enzyme types on the basis of action patterns against a series of substrates; and 2, to determine whether cane invertase, derived from a highly developed plant species, is identical with the invertase of a primitive plant form. Cane invertase was prepared from lyophilized immature storage tissues, while yeast invertase was obtained commercially as a desiccated extract of yeast cells.

Substrates included sucrose, raffinose, stachyose, melibiose, inulin, and soluble potato starch. The cane-invertase complex gave evidence of three carbohydrases: $\beta$-fructosidase, $\alpha$-galactosidase, and $\alpha$-glucosidase. Yeast invertase gave only $\beta$-fructosidase activity. Both types of invertase were readily inhibited by silicon, and possible modes of silicon action are discussed.

Similarities were noted between sugarcane invertase and sugarcane amylase. The two cane systems appear more nearly identical than cane and yeast invertase. Cane invertase, a more highly versatile enzyme complex than yeast invertase, apparently reflects the more complicated biochemical requirements of a higher plant species.

\section{RESUMEN}

Se realizaron estudios comparativos de la invertasa de la caña de azúcar y de la de una levadura comercial. Fueron dos los objetivos: 1, Identificar 
tipos específicos de enzimas a base de los patrones de acción sobre una serie de substratos; y 2, determinar si la invertasa derivada de la caña de azúcar, que es una especie de planta superior, es idéntica a la invertasa derivada de la levadura, que es una especie primitiva de plant. La invertasa de la caña de azúcar se preparó de un tejido reservante tierno y liofilizado, mientras que la de la levadura se obtuvo de fuentes comerciales en forma de un extracto desecado de células de levadura.

Los substratos que se incluyeron en este estudio son la sacarosa, la estaquiosa, la melibiosa, la inulina y el almidón soluble de papa. El complejo de la invertasa de la caña reveló la presencia de tres carbohidrasas, a saber: $\beta$-fructosidasa, $\alpha$-galactosidasa y $\alpha$-glucosidasa. La invertasa de la levadura sólo reveló la acción de la $\beta$-fructosidasa. Ambos tipos de invertasa se inhibieron rápidamente por la acción del silicio. Se discuten posibles formas en que tuvo lugar la acción del silicio.

Se observaron similaridades entre la invertasa y la amilasa de la caña de azúcar. Los dos sistemas enzimáticos parecen tener más identidad entre sí que la invertasa de la caña y la de la levadura. La invertasa de la caña, un complejo enzimático de mayor grado de versatilidad que la invertasa de la levadura, aparentement refleja los más complicados requisitos bioquímicos de una especie superior de planta.

\section{LITERATURE CITED}

1. Ablyaer, S. H. A., and Pulatov, U. U., Effect of the porosity of the silica gels on the value of their induced absorption, Izv. Akad. Nauk. Uz. SSR. Ser. Fiz.Nat. Nauk. 8 (2): 90-1, 1964.

2. Adams, M., and Hudson, C. S., New methods for the purification of invertase and some properties of the resulting products, $J$. Am. Chem. Soc. 65: 1359-68, 1943.

3. Alexander, A. G., Hydrolytic proteins of sugarcane. The acid invertases, $J$. Aor. Univ. P.R. 49 (3): 287-307, 1965.

4. - - Invertases of sugarcane, Proc. IX Cong. Lalin Amer. Chem. Soc., San Juan, P.R., 1965.

5. - Effects of tungstell and molybdenum on sucrose content and hydrolytic enzymes of immature sugarcane, $J$. Agr. Univ. P.R. 49 (4): 429-42, 1965.

6. - In vitro effects of silicon on the action patterns of sugarcane acid invertase, J. Agr. Univ. P.R. (Submitted, Oct., 1967).

7. - Interrelationships of silicon and gibberellic acid in the production of sucrose by sugarcane, Proc. Intl. Soc. Sugar Cane Technol, 13th Cong., Taiwan, 1968.

8. - In vit ro effects of silicon on hydrolytic and oxidative enzymes of sugarcane, Proc. Intnl. Soc. Sugar Cane Technol., 13th Cong., Taiwan, 1908.

9. Ayres, A., Cane growth studies at Waipo Substation; Experiment E., Haw. Plant. Rec. 34: 445-60, 1930.

10. Baba, K., and Baba, A., Relation between protein and silicate in rice plants, Nippon Nogei Kagaku Kaishi 38 (8): 710-14, 1959.

11. Ballard, S. S., The spectrographic study of the distribution of mineral elements in sugarcane, Haw. Plant. Rec. 44: 183-6, 1940.

12. Ball, A., Chem. Ztg. 19: 1873, 1895.

13. Baumann, H., and Pigman, W., Natural glycosides and glycosidases, Chapter 
10 in: The Carbohydrates., edited by Ward Pigman, Academic Press Inc., New York, N.Y., 1957, pp. 592-3.

14. Dube, S. K., and Nordin, P., Isolation and properties of sorghum $\alpha$-amylase, Arch. Biochem. and Biophys. 94: 121-7, 1961.

15. Fruton, J. S., and Simmonds, S., General Biochemistry; 2nd ed., John Wiley \& Sons, Inc., New York, N.Y., 1963, p. 421.

16. Fischer, E., and Lindner, P., Ber. 28: 3034, 1895.

17. Hartt, C. E., Some effects of potassium upon the amounts of protein and amino forms of nitrogen, sugars, and enzyme activity of sugarcane, Plant Physiol. 9: 453-90, 1934.

18. Hassid, W. Z., and Ballou, C. E., Oligosaccharides. Chapter 9 in: The Carbohydrates, edited by Ward Pigman, Academic Press Inc., New York, N.Y., 1957, p. 517.

19. Hatch, M. D., and Glasziou, K. T., Sugar accumulation cycle in sugarcane: II. Relationships of invertase activity to sugar content and growth rate in storage tissue of plants grown in controlled environments, Plant Physiol. $\$ 8$ (3): 344-8, 1963.

20. Hatch, M. D., Sacher, I. A., and Glasziou, K. T., Sugar accumulation cycle in sugarcane: I. Studies on enzymes of the cycle, Plant Physiol. 86 (3): 338-43, 1963.

21. Hirst, E. L., Some aspects of the chemistry of the fructosans, Proc. Chem. Soc. 1957: 193-204.

22. Iler, R. K., Ion-exchange properties of crystalline hydrated silica, $J$. Colloid Sci. 19 (7): 648-57, 1964.

23. Laidlow, R.A., and Wylam, C.B., The structure of stachyose, J. Chem. Soc. 1958: 567-71.

24. McFee, D.R., and Tye, R., Adsorption of protein on dusts related to pneumonoconiose selectivity, J. Occupational Med. 9 (6): 269-75, 1965.

25. Mitsyuk, B. M., Vysotskii, F. F., and Polyakov, M. V., Dokl. Akad. Nauk.S.S.S.R. 155 (6): 1404-6, 1964.

26. Moulik, S. P., and Ghosh, B. N., Effect of temperature and pH on the gelation of silicic acid, J. Indian Chem. Soc. 40 (11): 907-10, 1963.

27. Myrback, K., in: The Enzymes; Vol. 4. ed. by Bayer, P. D., Lardy, H., and Myrback, K. Academic Press, New York, N.Y., Chapter 22, Invertases, pp. 379-96, 1960.

28. Neuberg, C., and Mandl, I., in Sumner, J. B., and Myrback, K., The Enzymes; Chap. 14-Academic Press Inc., New York, N.Y. pp. 527-50, 1950.

29. Neumann, N. P., and Lampen, J. O., Purification and properties of yeast invertase, Biochemistry 6 (2): 468-75, 1967.

30. Onuki, M., Proc. Imp. Acad. (Tokyo) 8: 496, 1932.

31. Onuki, M., Sci. Papers Inst. Phys. Chem. Res. (Tokyo) 20: 201, 1933.

32. Palmer, A., The specific determination and detection of glucose as a probable constituent radical of certain fructosans by means of notatin, Biochem. J. 48: 389-94, 1951.

33. Samuels, G., and Alexander, A. G., Influence of variable manganese and silicon on the nutrition, sugar production, and enzyme activity of immature sugarcane, J. Agr. Univ. P.R. (In press).

34. Vlasov, N. A., and Morgen, E. A., The state of silicic acid in aqueous solutions, Izv. Fiz.-Khim. Nauchn.-Issled. 6 (1): 192-9, 1964. 